\title{
Cryopreservation of Unfertilized Rat Oocytes by Ultrarapid Freezing
}

\author{
Naomi NAKAGATA \\ Nippon Institute for Biological Science, 2221-1 Shinmachi, Ome-shi, Tokyo 198 and Central \\ Laboratory for Medical Sciences, Division of Pathology, School of Medicine, \\ Juntendo University, 2-1-1 Hongo, Bunkyo-ku, Tokyo 113, Japan
}

(Received 21 February 1992/Accepted 15 May 1992)

\begin{abstract}
Unfertilized rat oocytes were placed in a highly concentrated solution of cryoprotectant (DAP 224:2 M dimethylsulphoxide, $2 \mathrm{M}$ acetamide, $4 \mathrm{M}$ propylene glycol in $\mathrm{PB} 1$ ) in $0.5 \mathrm{ml}$ samplimg tubes and then immediately immersed into liquid nitrogen ; thawing was conducted in a $37^{\circ} \mathrm{C}$ waterbath. After thawing, 630 out of 968 oocytes $(65.1 \%)$ were morphologically normal. After insemination in vitro of cryopreserved oocytes, the proportion of pronuclear oocytes with spermtail (s), male (s) and female pronuclei ( $8-10 \mathrm{~h}$ post insemination), and 2-cell embryos with two identical blastomeres (28-30 h post insemination) was $60.8 \%(152 / 250)$ and $29.8 \%(39 / 131)$, respectively. One hundred and fifty oocytes that were judged as pronuclear oocytes under the inverted microscope $8-10 \mathrm{~h}$ after insemination were transferred to the oviducts of pseudopregnant recipients; $18.7 \%(28 / 150)$ of the oocytes developed to normal young. - KEY WORDS : ultrarapid freezing, unfertilized rat oocytes
\end{abstract}

\section{超急速凍結法を用いたラット未受精卵の \\ 凍結保存について}

中潟直己

財団法人日本生物科学研究所

順天堂大学医学部共同病理研究室

従来, 実験動物の未受精卵の凍結保存に関し，マウス $[1,3,5,6,8,9,13]$, 八ムスター $[8,9,12]$ ラット $[7,9]$ およびスナネズミ［9]に拈いて報告が成されているが， 融解後の生存性および発生能は受精卵および胚に比べ, 一般に低いのが現状である $[2,4]$ 。また，融解した末受 精卵を体外受精し，得られた肧を移植することにより 産児が得られているのは, マウスのみであり $[1,3,5,6$, 13]，その他の動物種についてはまったく報告が成され ていない。最近, 著者は超急速的に凍結したマウス未受 精卵において, 融解後, 良好な生存性および発生能が得 られたことを報告した $[5,6]$ 。そこで本実験では，ほぼ
同椂な超急速凍結法を用いてラット未受精卵の凍結保存 を試み, 融解後の生存性, 受精能および新生児への発生 能について検討した。

\section{材料および方法}

供試卵：卵子は 10 iu PMSG と 10 iu hCGにより, 過排卵処理を施した Wistar-Imamichi 系幼若雌ラッ ト（4 週龄）の卵管膨大部より, hCG 投与後 15～16時 間に採取し，0.1\% hyaluronidaseを含む HTF 培地内 ［10］で卵丘細胞を除去した裸化卵子を凍結実験に供した。 
Table 1. The survival rate of cryopreserved rat oocytes after thawing

\begin{tabular}{ccc}
\hline No. frozen & No. recovered & No. morphologically normal \\
\hline 998 & $968(97.0)$ & $630(65.1)$ \\
\hline
\end{tabular}

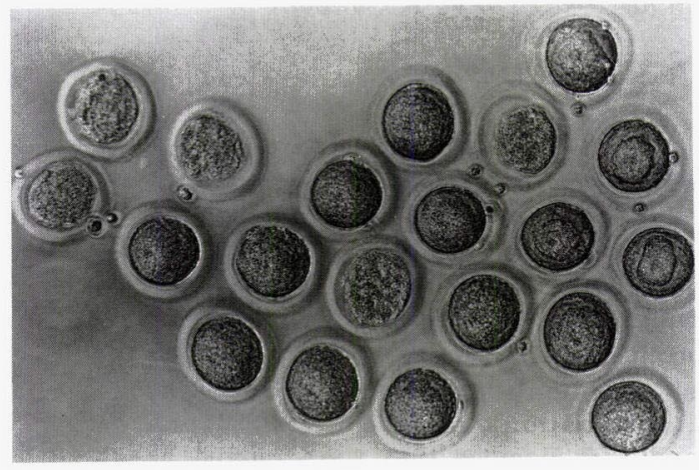

Fig. 1. Appearance of cryopreserved rat oocytes after thawing. About two thirds of the oocytes were morphologically normal.

凍結・融解 : 凍結·融解操作はほぼ前報 $[5,6]$ に従っ たが，保存液および融解操作に若干の改良を加えた。即 ち, 卵子は直接サンプリングチューブ (volume : $0.5 \mathrm{ml}$, Sarstedt Co., Ltd) 内の20 30 $\mu$ lの DAP 224(dimethyl sulphoxide $2 \mathrm{M}$, acetamide $2 \mathrm{M}$, propyleneglycol $4 \mathrm{M}$ in PB1) に移した後（1サンプリングチューブ当 たり $25 \sim 30$ 個) $5 \sim 10$ 秒以内に, 直接, 液体窒素中に浸 漬することにより行なった。融解は凍結してから 1 30 週間後に液体窒素保管器よりサンプリングチューブを 取り出し, $37^{\circ} \mathrm{C}$ の温水中に移すと同時に, $37^{\circ} \mathrm{C}$ の $0.5 \mathrm{M}$ sucrose 溶液を $0.4 \mathrm{ml}$ サンプリングチューブ内に加え, DAP 224 を希釈, その内容液を時計血に移し， 5 分間 静置した後, 卵子の回収を行なった。続いて, 回収卵子 を約 $20 \sim 30 \mu 1$ の内容液と共に, HTF 培地内 $(0.2 \mathrm{ml})$ に移した後 5 分間静置, さらに HTF 培地で 3 回, 卵子 を洗浄、それら卵子の形態的検査を行なった。

体外受精および得られた受精卵の移植 : 体外受精は Toyoda らの方法 [11] に従った。即ち, 精子は WistarImamichi 系成熟雄 ( 5 〜 6 力齢) の精巣上体尾部よ り採取し, HTF 培地に懸濁, さらにその一部を $0.4 \mathrm{ml}$ の HTF 培地に導入し(精子濃度 : 200 cells $/ \mu 1$ ), $5 \sim 6$ 時間の前培養を行なった（ $37^{\circ} \mathrm{C} 5 \% \mathrm{CO}_{2}$ in air $)$ 。続、
て, 形態的に正常と判定された卵子を精子懸濁液に移

し, 媒精を行なった。卵子の受精能についての観察は媒 精後 $8 \sim 10$ 時間にホールマウント標本を作製することに より行なった。また, 倒立顕微鏡下で第 2 極体, 精子尾 部および雌雄前核を確認した一部の前核期受精卵を偽 妊娠第 1 日目 (腔栓確認日) のレシピエント (LongEvans 系雌ラット： $3 \sim 4$ カ月跲）の卵管内へ移植し た。さらに, 残りの卵子については引き続き20時間（媒 精後28〜30時間）体外培養し， 2 細胞期への発生につい て検討した。尚, 卵丘細胞を除去した裸化卵子を単に体 外受精したものを対照区とした。また，凍結卵子の体外 受精成績扣よび移植成績について， $x_{2}$ 検定により，未 凍結卵子の成績と比較検討した。

\section{成 績}

Table 1 に融解時において形態的に正常と判定された 卵子の割合を示す。凍結卵998個の内, 融解後, 968個を 回収, その内の $65.1 \%$ に当たる 630 個が形態的に正常で あった（Fig. 1)。

体外受精成績 : 媒精後 $8 \sim 10$ 時間にホールマウント標 本を作製することにより観察した受精成績を Table 2 に示す。第 2 極体, 精子尾部および雌雄前核を有する正 常な受精卵 (Fig. 2) の割合は, 検査卵 250個中152個 （60.6\%）であり，その内の 21個が多精子受精卵であっ た。また，媒精28～30時間後に 2 細胞期へ発生した卵子 の割合は 29.8\%（39/131）と低值であった（Table 3 お よび Fig. 3)。一方, 対照区における受精率および 2 細胞期一発生率は，それぞれ88.0\% (125/142) 打よび 86. $2 \%(75 / 87)$ と, 凍結卵のそれらと比較すると, 有 意に高值を示した $(p>0.05)$ 。

移植成績 : 媒精後 $8 \sim 10$ 時間に実体顕微鏡および倒立 顕微鏡下で第 2 極体, 精子尾部および雌雄前核の有無 により判定した前核期受精卵の割合は61.0\% (152/249) であり, その内の150個をレシピエントへ移植した結果, 28匹 (18.7\%) の新生児が得られた（Table 4 拈よび Fig. 4)。しかしながら凍結融解卵子より得られた前核 期受精卵の新生児への発生率は対照区（53.6\%，44/82） と比較すると明らかに低い值であった（ $p>0.05 ） 。$

\section{考察}

本実験結果から，簡略な超急速凍結法によりラット未 受精卵の凍結保存が可能となり, それら凍結一融解卵は 体外受精により, 受精し, 少なくともその一部は新生児 
Table 2. The fertilization rate of cryopreserved rat oocytes $8-10 \mathrm{~h}$ after insemination in vitro

\begin{tabular}{|c|c|c|c|c|}
\hline \multirow{2}{*}{ Group } & \multirow{2}{*}{$\begin{array}{l}\text { No. of oocytes } \\
\text { examined }\end{array}$} & \multicolumn{3}{|c|}{ No. of oocytes fertilized* } \\
\hline & & Total $(\%)$ & Monospermic & Polyspermic \\
\hline Frozen-thawed & 250 & $152(60.8)$ & 131 & 21 \\
\hline Control(unfrozen) & 142 & $125(88.0)$ & 107 & 18 \\
\hline
\end{tabular}

* Pronuclear oocytes (oocyte with sperm tail(s), and male(s) and female pronuclei)

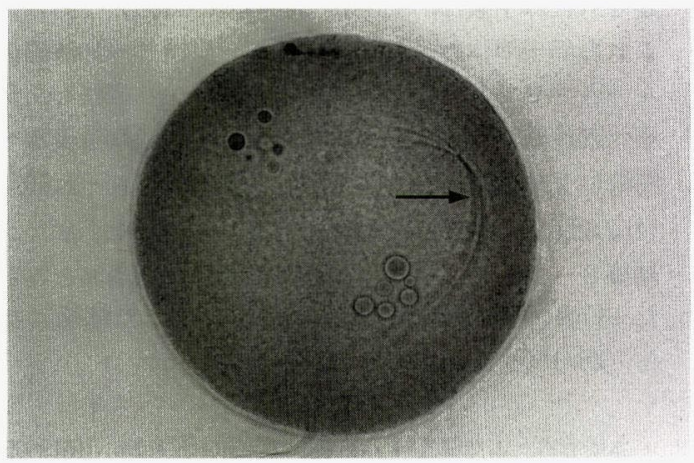

Fig. 2. Cryopreserved rat oocyte examined $8 \mathrm{~h}$ after insemination. A fertilized oocyte showing sperm tail (arrow), and mail and female pronuclei.

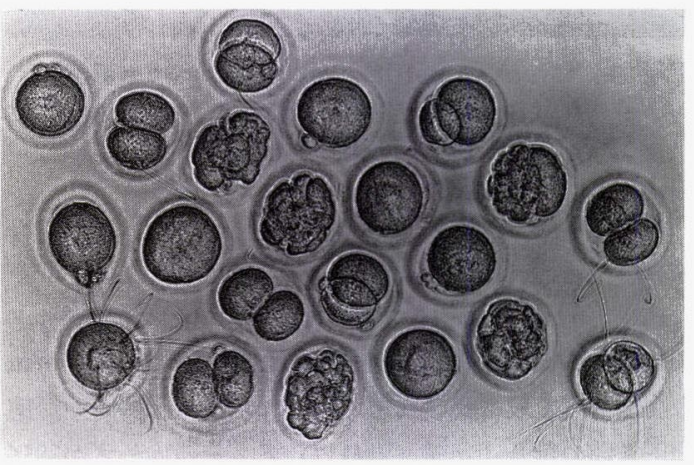

Fig. 3. Appearance of cryopreserved and in vitro fertilized rat oocytes at the 2-cell stage $28 \mathrm{~h}$ after insemination. Only one third of the cryopreserved oocytes developed to normal 2cell embryos.

Table 3. Development of 2-cell embryos from cryopreserved rat oocytes $28-30 \mathrm{~h}$ after insemination in vitro

\begin{tabular}{lcc}
\hline \multicolumn{1}{c}{ Group } & $\begin{array}{l}\text { No. of oocytes } \\
\text { examined }\end{array}$ & $\begin{array}{l}\text { No. }(\%) \text { of oocytes } \\
\text { developed to 2-cell stage* }\end{array}$ \\
\hline Frozen-thawed & 131 & $39(29.8)$ \\
Control (unfrozen) & 87 & $75(86.2)$ \\
\hline
\end{tabular}

* 2-cell embryos with two identical blastomeres

Table 4. Development to live young of pronuclear oocytes derived from cryopreserved rat oocytes after transfer to pseudopregnant recipients

\begin{tabular}{|c|c|c|c|c|c|c|}
\hline \multirow{2}{*}{ Group } & \multirow{2}{*}{$\begin{array}{l}\text { No. of } \\
\text { recipients } \\
\text { used }\end{array}$} & \multirow{2}{*}{$\begin{array}{l}\text { No. of } \\
1 \text {-cell embryos } \\
\text { transferred }\end{array}$} & \multirow{2}{*}{$\begin{array}{l}\text { No. of animals } \\
\text { which delivered } \\
\text { live young }\end{array}$} & \multicolumn{3}{|c|}{ No. of live young } \\
\hline & & & & 우 & $0^{x}$ & Total $(\%)$ \\
\hline Frozen & 9 & 150 & 7 & 16 & 12 & $.7)$ \\
\hline Control (unfrozen) & 6 & 82 & 6 & 24 & 20 & $44(53.6)$ \\
\hline
\end{tabular}




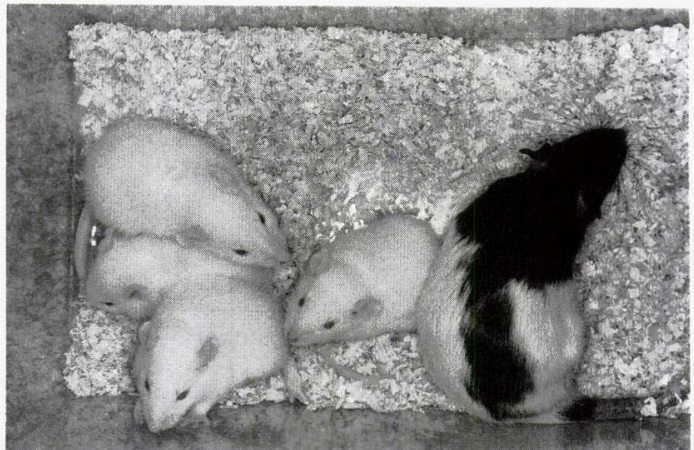

Fig. 4. Twenty-one-day-old young developed from cryopreserved oocytes fertilized in vitro, with their recipient mother

へ発生することが知られた。

Parkening 5 [8]は, 種々の冷却速度で幼若ラット より採取した未受精卵を緩慢凍結した結果， $0.33^{\circ} \mathrm{C} / \mathrm{min}$ の冷却速度で最も良好な值が得られたが，融解時の形態 的正常卵の割合は18\%（21/117）で，その内わずか38\% （8/12）が受精したにすぎなかったことを報告している。 Niwa らも [7] 幼若ラットの未受精卵を凍結し, 融解 後, その生存性について検討した結果, 融解時の形態的 正常卵の割合は, 回収卵のわずか14〜24\%であり, 正常 な受精卵あるいは 2 細胞期へ発生した卵子の割合は，そ の内の28.6 48.3\%であったと報告している。本実験に おける融解時の形態的正常卵の割合, 受精率および 2 細 胞期へ発生した卵子の割合は, これら報告に比べ, 高い 值であった。しかしながら，受精率が60.8\%であったに もかかわらず， 2 細胞期へは29.8\%しか発生せず, 異常 分割卵あるいは不等分割卵などの異常受精卵が高頻度に 観察されたこと,さらに, 移植卵に対する新生児への発 生率はわずか，18.7\%と極めて低く，発生が進むにつれ て急激にその割合が低下することから，一見，形態的 には正常でも, 凍結一融解操作に起因した何らかの傷害 が，卵子内に起こっている可能性が強く示唆された。

採卵時の雌ラットの週龄について, Parkening ら [8] は幼若および成熟ラットより得られた卵子を凍結し，融 解後の生存性について比較検討した結果, 成熟ラット卵 子の方が幼若ラットのそれと比べ, 有意に高い生存性が 得られることを報告している。今回, 本実験で用いたラ ットは 4 週齢の幼若ラットであり, 必ずしも良好な生存 性が得られなかったことから, 今後, 成熟ラット卵子の 超急速凍結も検討する必要があると思われる。
要 約

室温にて卵子をサンプリングチューブ内の DAP 224 (dimethyl sulphoxide $2 \mathrm{M}$, acetemide $2 \mathrm{M}$, propylene glycol $4 \mathrm{M}$ in PB1) に移した後, 直ちに, 液体 窒素中に浸漬することにより，ラット未受精卵の超急 速凍結を行なった。また, 融解は $37^{\circ} \mathrm{C}$ の温水中で行なっ た。融解後に, 回収した卵子の中で, 形態的に正常と判 定された卵子数は，968個中630個（65.1\%）であった。 これら卵子の体外受精成績, 即ち, 媒精 $8 \sim 10$ 時間後に ホールマウント標本を作製することにより観察した受精 率（前核期へ発生した卵子の割合）および媒精後28～30 時間に 2 細胞期へ発生した卵子の割合はそれぞれ $60.8 \%$ （152/250）および29.8\%（39/131）であった。また，媒 精後 $8 \sim 10$ 時間に倒立顕微鏡下で前核期受精卵之判定し た 150個の凍結卵を偽妊娠雌卵管へ移植した結果， 18.7 \%（28/150）が正常な新生児へ発生した。

本研究は, 本文部省科学研究費重点領域研究 No. 01619005の 一部として実施された。

\section{文献}

[1] Carroll, J., Warnes, G. M., and Matthews, C. D (1989). Increase in digyny explains polyploidy after in-vitro fertilization of frozen-thawed mouse oocytes. J. Reprod. Fert., 85, 489-494.

[2] Friedler, S. F., Giudice, L. C., and Lamb, E. J.(1988). Cryopreservation of embryos and ova. Fertil. Steril. 49, 743-764.

[3] Glenister, P. H., Wood, M. J., Kirby, C., and Whittingham, D. G. (1987). Incidence of chromosome anomalies in first-cleavage mouse embryos obtained from frozen-thawed oocytes fertilized in in vitro Camete Research, 16, 205-216.

[4] Leibo, S. P. (1986). Cryobiology : preservation of mammalian embryos. Basic Life Sci, 37, 251-271.

[5] Nakagata, N.(1989). High survival rate of unfertilized mouse oocytes after vitrification. J. Reprod Fert., 87, 479-483.

[6] Nakagata, N. (1990). Cryopreservation of unfertilized oocytes from inbred strains by ulirarapid freezing. Exp. Amin., 39, 303-305.

[7] Niwa, K., Kasai, M., and Iritani, A.. (1979). Fertilization in vitro of rat eggs after freezing and thawing. Jap. J. Zootech. Sci.50, 747-752.

[8] Parkening, T. A., Tsunoda, Y., and Chang, M. C. (1976). Effects of various low temperature, cryoprotective agents and cooling rates on the survival, fertilizability and development of frozen-thawed mouse eggs. J. Exp. Zool, 197, 369-374.

[9] Parkening, T. A. and Chang, M. C. (1977). Effect of cooling rates and maturity of the animal on the recovery and fertlization of frozen-thawed rodents 
eggs. Biology of Reproduction, 17, 527-531.

[10] Quinn, P. Q., Kerin, J. F., and Warnes, G. M. (1985). Improved pregnancy rate in human in vitro fertilization with the use of a medium based on the composition of human tubal fluid. Fertil. Steril, 44, 493 -498 .

[11] Toyoda, Y. and Chang, M. C. (1974). Fertilization of rat eggs in vitro by epididymal spermatozoa and the development of eggs following transfer. $J$.
Reprd Fert., 36, 9-22.

[12] Tsunoda, Y., Parkening, T. A., and Chang, M. C. (1976). In vitro fertilization of mouse and hamster eggs after freezing and thawing. Expermentia, 32, 223-224.

[13] whittingham, D. G. (1977). Fertilization in vitro and development to term of unfertilized mouse oocytes previously stored at $-196^{\circ} \mathrm{C}$. J. Reprod. Fert., 49, 89-94. 